\title{
THE GRAMMATICAL ERRORS IN THE TRANSLATIONAL TEXT: INDONESIAN-ENGLISH STRUCTURE
}

\author{
Nurul Aini \\ Universitas Negeri Yogyakarta, Jl. Karangmalang \\ Nurul.aini2016@student.uny.ac.id
}

\begin{abstract}
This paper discussed the study of English and Indonesian word construction based on grammatical errors. Grammatical errors were analyzed by error analysis. The purpose of this paper wanted to know the kinds of grammatical errors and the factors caused it. The qualitative approach was used in this research as the methodology because this study described the data without analysis statistic. The qualitative descriptive revealed the phenomena of linguistic which found in the translation text. In data collection, the researcher used text translation, Indonesian-English that had translated by the fourth semester of student's English Department. Moreover, the researcher read deeply and grouped and noted the data to find the valid data. The result of this paper were 11 kinds of grammatical errors, they are: misuse of determiner, omission of determiner, misuse of verb, misuse of auxiliary verb, omission of verb, misuse of preposition, misuse of conjunction, misuse of pronoun, omission of pronoun, misuse of singular noun, and misuse of Noun Phrase (NP). In addition to, this study found the factors of the grammatical errors, they are; first, interference of the first language, namely Indonesian. Second, the difference between Indonesian and English structure was also the factor of the grammatical errors.
\end{abstract}

Keywords: grammatical errors, translation, Indonesian-English structure, factors

Today, translation becomes an important activity. The translation process was an activity which translator had to change source language to other languages. According to Catford (1965: 20) translation may be defined as follows: the replacement of textual material in source language by equivalent textual material in the target language. Translation is change of a source language into the target language, so that to confirm that firstly, the meaning of surface of the language would approximately similar, and secondly, the structures of the source language would not be change, it preserved as closely as possible but not so closely the target language structures would be seriously distorted (McGuire \& Bassnet in Farkhan 2014: 351).

Indonesian as development country was the country that has consideration with another country English. Most articles and journals were written in English. English became a lingua franca that the most important in translation where all research papers, book, and others should be translated into English. For Indonesian learners, translating Indonesian to English was not an easy task. English and Indonesian had similarity and differences. The similarity both of them was based on Cook (1988: 1) in his book. He said that universal grammar theory holds that the speaker knows a set of principles that apply to all language. It showed that people have same principles in their language. In another hand, English is a Germanic language within the Indo-European language family (Chan 2004; Li \& Thompson, 1981). Meanwhile, Indonesian is not related, every remotely, to English. Indonesian is to an Austronesian language family which extends across the islands of Southeast Asia and Pacific (Quinn, 2001). Soeparno (2013: 41) said that English was flection and agglutinative language while Indonesian was agglutinative language. Any (2013:11) also said that English was inflection language so as it has the different form such tenses change. From that differences, translation activity was a difficult activity.

In the other hand, the most important in translation conveyed the messages. It was one of the starting points in translation. Hence, the reader could understand the text. Larson (1988: 3) said that the translations were: (1) learning lexicon, grammatical, situation of communication and the context of culture of source text, (2) analyzing source text to find the meaning; and (3) rearrange the meaning in source text into target 
text by using appropriate lexicon and grammatical of target text. In this research, Indonesian was the source text (TSu) while, English was the target text (TSa).

An error could be analyzed to make clear in the learning process. The analyzed of errors were undoubtedly valuable teaching tools, and the teacher should handle them cautiously and with an awareness that all have their faults, on which the researcher had also validly criticized Contrastive analysis and Error analysis (Tarone in Wang 2008: 186). In the book "Error and Interlanguage" written by Pit Corder, the "Father" of Error Analysis (1981), he stated that various classifications of these error systems have been developed by error analysis researchers, three of which could be helpful for the teacher and are as follows (Wang, 2008: 185).

Moreover, some previous studies discussed the grammatical error was like the research entitled syntactic error in descriptive paragraphs by native Indonesian-speaking students of English (Basri et al, 2013). Correcting grammatical error in university-level foreign language students' written work (Griffits \& Sonmez, 2015), and Errors in second/foreign language learning and their interpretations (Wood, 2017). The previous studies talked about errors in writing and speaking. The student's writing contained the concept while in the translation the student analyzed the source text then rearrange the concept and the grammar of the source text into the target text. The studies of grammatical errors continually carried on among some languages. Based on some cases in written text in the previous studies, the researcher was interested to research the grammatical error yet in the translational text. Based on the introduction, there were two research questions as follows:

1. What was kind of grammatical error in the Indonesian- English translation?

2. What were the factors of the grammatical error in Indonesian-English translation?

\section{Literature review}

Utilizing incorrect grammatical can be said as a grammatical error. Hancock (2005:6) states that grammar is an intrinsic meaning maker of a language that rules in arranging a set of words in order to form meanings. According to Amando et al (2008: 23) said there has always been a generally accepted concept that if you break grammatical or structural rules you have made a mistake. Errors were an incorrect thing: An error was something that was incorrect, and, therefore, more or less by definition, a bad thing (Griffiths \& Sonmez, 2015: 60).

Error analysis was the type of approach to analyze the second language or the foreign language learners' performance (Garza \& Wu, 2014: 1256). Based on error analysis, the teacher could understand the difficulty that their student faced in the learning process.

Corder (1967) in Wood (2017: 4) distinguished error and mistake, namely a mistake was related to physical conditions (fatigue) or to psychological conditions (strong emotions), and an error was the result of a transitory competency in L2. Later on, errors classified in three types, namely; pre-systematic (the learners did not know the grammatical of the second language), systematic (the learners knew the grammatical of the second language but the learners used it unwell, and post-systematic (the learners knew the grammatical but the learners had a weak concentration so that the rule of language was not used.

In another hand, George (1972: 2) said that an error was unwanted form, specifically, a form which a particular course designer or teacher did not want. While David \& Pearse (2002: 103) said that error was a part of language learning, it was not evidence of the failure in the learning process. According to Brown (2007:

226), an error is a deviation from the adult grammar of native speakers which signifies the inter language capability of the language learners.

Burt and Kiparsky (1972) in Yang (2010: 266) suggest that the researcher or the teacher should identify errors by reference to the target language. James in Sattayatham \& Honsa (2007: 173-175) classified error into two kinds, they are; linguistic category taxonomy and surface structure taxonomy. Linguistic category taxonomy distinguished the error by linguistic category. Error in this area occurred in phonology, syntactic and text or discourse. Surface structure category was initiated by Dulay, Burt, and Krashen (1982: 150) that showed surface structure change. According to them, the error occurred 
specifically and systematically. The error in this taxonomy was divided into four kinds, namely; 1) omission, 2) addition, 3) misformation, and 4) misordering.

Omission occurred in the sentence when one or two component of language needed was missing. For example, you know what you want? In fact, in English question sentence auxiliary do preceded subject, hence the correct sentence was $\underline{d o}$ you know what you want?. Contrarily, the addition was an error that added one or two language component in the sentence. the word was unnecessary in the sentence such he does not knows me, whereas if the sentence contained the auxiliary do or does of the verb has to bare infinitive so as the correct sentence was he does not know me. Missformation was kind of an error in language construction. For example, I buy a bag yesterday. The concept of that sentence was in past so the form of the verb added $\mathrm{d}$ or ed in regular verb and some verbs have certain form so as the correct sentence was I bought a bag yesterday. Missordering was an error in sentence structure. Using incorrect structure such the research background is the understanding of teacher regarding exact matter subject in teaching learning activities. In fact, the correct sentence was the research background is the understanding of teachers regarding exact subject matter in teaching learning activities. (Any, 2013: 11).

Richard in Bagheri \& Heydari (2012: 1548) proposed errors based on its cause. Based on it errors divided into two types: first, interlingual errors and intralingual errors. Interlingual errors were caused by interference of the first language or the mother tongue. Whereas, intralingual errors is caused by the grammatical of the language. Weinreich in Dittmar (1976) in Any (2013: 12) divided interference of grammatical as follows: (1) utilizing language A in language B, (2) using the relationship of grammatical of language A into language B or the denial of grammatical relation of language B, and (3) a change in morpheme function that produced (added or reduced the function of morpheme of language $\mathrm{B}$ based on grammatical language $\mathrm{A}$.

\section{Research Methodology}

This study was qualitative descriptive. Qualitative descriptive revealed the phenomena of linguistic which found in the translation text. In this study, the researcher discussed the finding of grammatical errors in the text translation. In qualitative descriptive method, the data described factual and accurate clearly.

\section{Subjects}

The subjects of this study were the fourth semester of students' English department of IAIN Samarinda who had passed the writing 1,2, and basic translation. In the fourth semester, they learn the intermediate subject. Amount of the students as respondents were 52 students divided into two classes, namely TBI 1 and TBI 2 . The source of data was the text that has translated by them. They had translated the different of the source text-Indonesian into the target text-English. They translated were about in 40 minutes. The data were the incorrect grammatical in the target text.

\section{Data collection}

To obtain the data, the instructor collected all the result of the translation. The source text was translated into English as a target text. The data were the sentence that contained incorrect grammatical in the target text. In the data collection, the researcher used three stages; first reading the data, grouping, and noting them in the data card. The text translations were collected and analyzed to found the various errors and counted the frequency of errors.

\section{Data Analysis}

After collecting data, the data were analyzed. To analyze the data, the researcher used the concept in language research. According to Sudaryanto, the researcher used padan translational in analyzing the data. Padan translational use another language to identify the first language (Sudaryanto, 2015: 17). In this study, the researcher analyzed the common errors in their target text. Common grammatical errors were seen as most frequent grammatical errors appeared in target text. The Indonesian language used to compensate English. Hence, the cause of errors in English could be known.

\section{Findings}

In order to answer this research questions, 52 text translations were collected and the kinds and manners of errors about were tabulated. The contents of tables were exposed for the sake of the providing the statements. The kinds of grammatical errors as follows: 
Tabel 1: kinds of error

\begin{tabular}{|c|c|c|c|c|}
\hline No. & Feature & Quantity & Example & Correction \\
\hline 1. & $\begin{array}{l}\text { Misuse of } \\
\text { determiner }\end{array}$ & 8 & $\begin{array}{l}\text { An Moslem } \\
\text { philosopher }\end{array}$ & A Moslem philosopher \\
\hline 2. & $\begin{array}{l}\text { Omission of } \\
\text { pronoun }\end{array}$ & 1 & $\begin{array}{l}\text { But know all of the } \\
\text { parts is life }\end{array}$ & $\begin{array}{l}\text { But we know all of the } \\
\text { parts is life }\end{array}$ \\
\hline 3. & $\begin{array}{l}\text { Misuse of } \\
\text { the auxiliary } \\
\text { verb }\end{array}$ & 3 & $\begin{array}{l}\text { We are don't } \\
\text { know... }\end{array}$ & We don't know \\
\hline 4. & $\begin{array}{l}\text { Misuse of } \\
\text { NP }\end{array}$ & 3 & In body we & In our body \\
\hline 5. & $\begin{array}{l}\text { Misuse of } \\
\text { preposition }\end{array}$ & 11 & $\begin{array}{l}\text { We can see of his } \\
\text { creature }\end{array}$ & We can see his creature \\
\hline 6. & $\begin{array}{l}\text { Misuse of } \\
\text { singular } \\
\text { noun }\end{array}$ & 6 & $\begin{array}{l}\text { We know all of the } \\
\text { part ... }\end{array}$ & $\begin{array}{l}\text { We know all of the } \\
\text { parts ... }\end{array}$ \\
\hline 7. & $\begin{array}{l}\text { Misuse of } \\
\text { verb }\end{array}$ & 37 & $\begin{array}{l}\text { He is exist in } \\
\text { everywhere }\end{array}$ & He exists everywhere \\
\hline 8. & $\begin{array}{l}\text { Omission of } \\
\text { determiner }\end{array}$ & 60 & Soul of our body & The soul of our body \\
\hline 9. & $\begin{array}{l}\text { Misuse of } \\
\text { conjunction }\end{array}$ & 3 & This same with... & This same as... \\
\hline 10. & $\begin{array}{l}\text { Misuse of } \\
\text { pronoun }\end{array}$ & 3 & $\begin{array}{l}\text { Him exist in } \\
\text { everywhere }\end{array}$ & $\underline{\mathrm{He}}$ exists in everywhere \\
\hline 11 & $\begin{array}{l}\text { Omission of } \\
\text { verb }\end{array}$ & 2 & God only one & God is the only one \\
\hline & Total & \multicolumn{3}{|l|}{137} \\
\hline
\end{tabular}

\section{Discussion}

Based on the analyzing data above, the researcher found 11 grammatical error forms as follows:

\section{Misuse of determiner}

TSu: seorang filsuf muslim...

TSa: An Moslem philosopher...

The function of determiner was the modifying the noun. One of kinds of determiner was article. The Article alan is preceded by the singular noun. In that noun phrase the correct article is $a$. hence, the sentence should A Moslem philosopher. The other misuses of determiner were the certainly, one existence. In fact, article could not modify the adverb so that certainly occurred without the. Moreover, the translation of eksistensi should be translated the existence. It was not preceded cardinal number. Hence, its translation should certainly and the existence.

\section{Omission of pronoun}

TSu: Namun kita tahu bahwa semua bagian itu hidup...

TSa: But know all of the parts is life...

In the source text, there was pronoun as a subject but in the target text the translator omitted the subject. The sentence was minimally established by a subject and a predicate. The translator should attend a subject and a predicate to make the simple sentence so as the correct sentence was but we know all of the parts is life...

\section{Misuse of the auxiliary verb}

TSu: kita tidak tahu pasti

TSa: He don't know exactly 
The translator translated that sentence literally. Whereas, In English, there was subject verb agreement. An auxiliary do preceded the main verb in the sentence. The subject such as I, we, you, and they used auxiliary do in the negative sentence. Meanwhile, there was does that preceded she, he and it. Therefore, the correct sentence was we do not know exactly. Based on the target text, the translator did not know the subject-verb agreement of English. Other examples of this kind of error were we can to feel it, modal cannot be followed to. On the other hand, Aarts (2001: 36) said that the subdivision in the class of auxiliaries. This class could be subdivided into four groups, they are; first, modal auxiliary; second, aspectual auxiliary; third, the passive auxiliary, and fourth, auxiliary do. The learners added to in their construction but the translation

\section{Misuse of Noun Phrase word order}

TSu: di dalam tubuh kita

TSa: in body we

An English noun phrase is not like as Indonesian noun phrase. In Indonesian, the structure of NP is noun + modifier. The noun (head) in Indonesian noun phrase preceded modifier, but quantity as modifier could attend before the head (Nababan, 2003: 56). Meanwhile, in English, the NP is constructed by modifier + noun. Possessive adjective modifies the noun. Hence, the correct translation is in our body. Yet, the translator used the rule of Indonesian to translate into English so that the translation was incorrect.

\section{Misuse of preposition}

TSu: jiwa di tubuh kita

TSa: part on our soul

That translation could be confusing. The correct translation should the soul of our body. There was confusing structure based on the structure of English phrase. The preposition on used to reveal the location. The correct preposition is of in that part. Another incorrect translation was the part from our body.

\section{Misuse of singular noun}

TSu: di setiap tempat

TSa: in every inches

The result of that translation was incorrect surface structure in English. First, every was singular so that the word that preceded it had to singular. The correct translation was in every inch. Second, the word choice to translate tempat was incorrect. The translator could translate such in everywhere or in every place. The other kinds of this error were all the creature, all of part, in every places, this things. Its translation should all the creatures, all of parts, and in every place, these things or this thing.

\section{Misuse of verb}

TSu: Semua bagian itu hidup

TSa: All those parts is life

That clause consisted of subject and predicate. The subject was plural form but the predicate of that clause was singular. The translator had to pay attention the subject verb agreement. Other example such as to arrived first time, we are don't know exactly, all of the parts were lived. The correct translation should to arrive first time (to + bare infinitive), we do not know exactly (without auxiliary verb), and all of the parts live.

\section{Omission of determiner}

TSu: di angkasa

TSa: in space

A noun was modified by the determiner. The function of determiner was describing or limiting the noun. Determiner could consist of article; the, an, and a. In that noun phrase could be preceded by the or $a$ so that the construction of noun phrase should in the space. Other examples of these kinds of error such as astronaut from Rusia, soul of our body, existence of God. Its translation should be the astronauts from Rusia, the soul of our body, the existence of God.

\section{Misuse of conjunction}

TSu: sama dengan keberadaan Tuhan di dunia ini. 
TSa: same like the existence of God in this world.

The translator translated the sentence literally. Sama dengan translated word by word so that the surface translation is same with. In English there was no same like but the correct is same as. Another example is the same with the existence of God in this world.

\section{Misuse of pronoun}

TSu: Dia berada di setiap tempat

TSa: him exist in everywhere

There was incorrect pronoun. In source text, the subject was the third person. In English, there was subject pronoun such as I, you, we, they, she, he, and it. In addition to, there was object pronoun that it was function as an object such as I-me, you -you, she -her, we-us, he -him, etc. Hence, its translation should he exists in everywhere.

\section{Omission of verb}

TSu: Tuhan hanyalah satu

TSa: God only one

This translation had translated word by word. Some sentences can be translated word by word such saya (I) pergi (go) ke (to) sekolah (school), I go to school. Yet, some sentences had to rearrange in English. A simple sentence consists of a subject and a predicate so that the correct is The God is the only one. Another example of this kind of grammatical error was but his existence in every place in this world. There was no verb in that translation. The correct translation should he exists in every place in this world.

\section{Conclusion}

By the finding and discussion of the data above, the researcher concluded some kinds of grammatical errors as follows:

First, there are 11 grammatical errors that found in the target text. The kinds of errors are consist of misuse of determiner, omission of error, misuse of verb, misuse of auxiliary verb, omission of verb, misuse of pronoun, omission of pronoun, misuse of conjunction, misuse of preposition, misuse of Noun Phrase (NP). The highest errors was omission of determiner, misuse of verb, and misuse of preposition.

Second, based on the analyzing, many sentences had translated word by word or literally method although Indonesian and English have different structure. In fact, the literal method could not be used in the different rules of language. Some translators did not know how to arrange the noun phrase and the verb phrase because the translator did not know the English grammatical so as they used Indonesian's structure to arrange them. The rule of Indonesian as the first language of the learners caused it was used in the translation process.

Third, some factors that caused error as follows: the interference of the first language. When the learners translated the source text into the target text who they did not know the rules of English they used the rules of Indonesian language to arrange the result translation. The mastery of grammatical of the source text and target text certainly became the constraints for the translator. In translation process, it often occurred when transferred of the meaning of source language or source text into the target language of the target text which involved the form or the grammatical both of them. In other hands, the differences of Indonesian and English also affected in the translation process.

From my research and previous studies, there were too many errors of noun phrase construction included the determiner as modifier, secondly, there was incorrect subject verb agreement, so on. Based on these errors, the differences of Indonesian and English language could be confusing for the English learners.

Most sentences above translated word by word or literally. To get the good result of translation, the translator should avoid the word by word or the literal method to translate the Indonesian into English vice versa because of their differences. The translator should be master in the rule of source text and target. In addition to, the translator should understand the culture of both languages.

\section{References}


Any, B. (2013). Interferensi Bahasa Indonesia ke dalam bahasa Inggris. Jurnal bahasa dan seni. No. 1. 1017.

Amando, V., L, et al. (2008). Teachers' attitudes towards correcting students' written errors and mistakes. Porta linguarum. 21-30. ISSN: 1697-7467.

Aarts, Bas. (2001). English syntax and argumentation $2^{\text {nd }} e d$. London: Palgrave.

Basri, D., Ampa. A. T \& Junaid. (2013) Syntactic error in descriptive paragraphs by native Indonesianspeaking students of English. Internasional Journal of Linguistics. Vol. Vol. 5 No. 5. 125-137. Doi: http://10.5296/ijl.v5i5.4455

Brown, H., D. (2007). Principles of language learning and teaching. $5^{\text {th }}$ Ed. San Fransisco : Longman Publishing Group.

Chan, Alice, Y., W. (2010). Noun phrases in Chinese and English: A study of English structural problems encountered by Chinese ESL students in Hongkong. Language, Culture, and Curriculum, 17:1, 3347. DOI:http://dx.doi.org/10.1080/07908310408666680.

Catford, J., C. (1965). A linguistic theory of translation. London: Oxford University Press.

Garza, E., B \& W., H. (2014). Types and attribute of English writing errors in the EFL context -A study of error analysis. Journal of language teaching and research. Vol. 5. No. 6, pp. 1256-1262. Doi. 10.4034/jltr.5.6.1256-1262.

George, H., V. (1972). Common Errors in language learning; Insight from English. Massachusetts: Newbury House Publisher.

Griffiths, C \& Sonmez, G. (2015). Correcting grammatical errors in university-level foreign language students' written work. KSJ. 3 (1). 57-74. http://ksj.pwsz.konin.edu.pl.

Hancock, Craig. (2005). Meaning - Centered Grammar: An Introductory Text. London: Equinox Publishing Ltd.

Larson, L, M. (1988). Penerjemahan berdasarkan makna: Pedoman untuk pemadanan antarbahasa. (Translated by Kencanawati Taniran, 1984). Jakarta: Arcan.

Muhammad Farkhan, (2014). Penyimpangan sintaksis dalam penerjemahan Indonesia-Inggris: Studi kasus di prodi sastra Inggris UIN Jakarta. Al-Turas. Vol. XX. No. 2, 349- 367

Nababan, Mangatur. (2003). Teori menerjemah bahasa Inggris. Yogyakarta: Pustaka Pelajar

Parkinson, J \& Musgrave, J. (2014). Development of noun phrases complexity in the writing of English for academic purposes students. Journal of English for academic purposes. pp. 48-59. DOI:http://dx.doi.org/10.1016/j.jeap.2013.12.001.

Paul, G. (2009). Translation in practice. Champaign and London: Dalkey Archive Press.

Quinn, G. The learner's dictionary of today's Indonesian. Sydney: Allen \& Unwin. ISBN 1864485434.

Soeparno. (2013). Dasar-dasar linguistik umum. Yogyakarta: PT Tiara Wacana.

Sudaryanto. (2015). Metode dan teknik analisis bahasa. Yogyakarta: Sanata Dharma University Press.

Yang, W. (2010). A tentative analysis of errors in language learning use. Journal of language teaching and research. Vol 1. No. 3, pp. 266-268.

Wang, (2008). Exploring errors in target language learning and use: Practice meets theory. English language teaching. Vol. 1. No. 2. 182-187

Wood, J, F. (2017). Error in second/foreign language learning and their interpretations. Education and linguistic research. Vol. 3 No. DOI:10.5296/elr.v3i1.10251. 